\title{
MENURUNKAN BERAT BADAN PADA WANITA USIA SUBUR (WUS) MELALUI SENAM AEROBIK DI DESA CIKONENG KECAMATAN SUKAHAJI KABUPATEN MAJALENGKA
}

\author{
Maya Nurhayati, Adi Susanto \\ Universitas Majalengka \\ mayanurhayati@unma.ac.id
}

\begin{abstract}
A healthy life with an ideal body weight is the dream of every woman. But in reality not all women have the ideal weight and to get it they need to make various efforts, one of which is to implement regular exercise and balanced nutrition. Based on this, it is necessary to carry out sports activities to invite people to maintain their physical health through aerobic exercise activities that aim to reduce the weight of women of childbearing age (WUS), so that their immune systems are better. practice of aeronic gymnastics and counseling on healthy exercise and balanced food intake to manage body weight, final data analysis and evaluation. Community service (PKM) is an activity of the Tridarma Physical Education Study Program, FKIP University of Majalengka in Cikoneng Village, Sukahaji District, Majalengka Regency. By doing regular aerobic exercise it is expected to be a measuring tool in an effort to increase the health status of women of childbearing age (WUS), and can increase public awareness of the importance of maintaining health. The expected output target of this service is an accredited national journal.
\end{abstract}

Keywords: Body Weight; Aerobic Gymnastic; WUS

\begin{abstract}
Abstrak
Hidup sehat dengan berat badan ideal adalah dambaan setiap wanita. Namun pada kenyataan tidak semua wanita memiliki berat badan yang ideal dan untuk mendapatkannya mereka perlu melakukan berbagai macam upaya, salah satunya adalah dengan menerapkan olahraga teratur dan asupan gizi seimbang. Berdasarkan hal tersebut maka diperlukan kegiatan olah raga untuk mengajak masyarakat agar memelihara kesehatan jasmani mereka melalui kegiatan senam aerobik yang bertujuan untuk menurunkan berat badan wanita usia subur (WUS), sehingga daya tahan tubuhnya lebih baik. Metode pengabdian ini menggunakan action reaserch, yakni persiapan, praktek senam aeronik dan penyuluhan mengenai olahraga sehat dan asupan makanan yang seimbang untuk mengatur berat badan, analisis data akhir dan evaluasi. Pengabdian kepada masyarakat (PKM) ini merupakan kegiatan Tridarma Prodi Pendidikan Jasmani FKIP Universitas Majalengka di Desa Cikoneng Kecamatan Sukahaji Kabupaten Majalengka.Dengan melakukan senam aerobik teratur diharapkan menjadi alat ukur dalam upaya meningkatkan derajat sehat wanita usia subur (WUS), serta dapat meningkatkan kesadaran masyarakat akan pentingnya menjaga kesehatan. Target luaran yang diharapkan dari pengabdian ini yaitu jurnal nasional terakreditasi.
\end{abstract}

Kata Kunci: Berat Badan; Senam Aerobik; WUS

\begin{tabular}{l|l|l} 
Submitted: $2020-08-02$ & Revised: $2020-10-10$ & Accepted: $2020-10-21$
\end{tabular}

\section{Pendahuluan}

Hidup sehat dengan berat badan ideal adalah dambaan setiap wanita. Namun pada kenyataan tidak semua wanita memiliki berat badan yang ideal dan untuk mendapatkannya mereka perlu melakukan berbagai macam upaya, salah satunya adalah dengan menerapkan pola diet beragam dan berolahraga. Beberapa penelitian menunjukkan bahwa prevalensi kelebihan berat badan telah menjadi masalah global, baik di Negara maju maupun di Negara berkembang. Kelebihan berat badan dapat berhubungan dengan berbagai macam penyakit, seperti hipertensi, penyakit jantung koroner, penyakit diabetes melitus, penyakit gangguan pernafasan pada usia lanjut, nyeri pinggang belakang (low back pain), radang sendi (arthritis), infertilitas, dan penurunan fungsi psikososial. Pada sepuluh tahun terakhir ini, kegemukan tidak hanya merupakan suatu penyakit atau keadaan yang banyak diderita oleh masyarakat di negara yang sudah maju, tetapi juga merupakan masalah di negara- negara yang sedang berkembang terutama pada kelompok sosial ekonomi tertentu. (Departemen Kesehatan Republik Indonesia 2012).

Beberapa cara untuk menangani kelebihan berat badan antara lain dengan berolahraga, diet dan terapi psikologis. Latihan fisik jauh lebih baik menurunkan berat badan dibandingkan dengan 
dua intervensi lain. Keuntungan lain dari latihan fisik terlihat pada senam aerobik selama 10-15 menit 3 kali seminggu yang dapat mengendalikan tekanan darah dan lemak darah. Latihan olahraga, sebagaimana kita ketahui bersama, mempunyai pengaruh yang jelas pada penurunan kadar lemak dan kolesterol di dalam darah kita. Tanpa melakukan latihan olahraga, kemungkinan untuk mendapatkan serangan penyakit jantung akan lebih banyak (Sadoso Sumosardjuno, 1990). Untuk mengurangi resiko hipertensi dan penyakit jantung koroner serta untuk meningkatkan kapasitas kerja fisik, Akademi Kedokteran Olahraga Amerika (The American College of Sport Medicine) merekomendasikan agar seseorang ikut serta dalam kegiatan olahraga aerobik minimum 3 kali seminggu selama 20 sampai 60 menit. Intensitas olahraga harus didasarkan pada suatu persentase dari kapasitas maksimum individu yang bersangkutan untuk bekerja (T. Cotton Richard, 1993).

Wanita usia subur (WUS) adalah wanita yang memasuki usia 1549 tahun tanpa memperhitungkan status perkawinannya. Wanita usia subur mempunyai organ reproduksi yang masih berfungsi dengan baik antara umur 20-45 tahun. Usia subur pada wanita berlangsung lebih cepat daripada pria. Puncak kesuburan ada pada rentang usia 20-29 tahun. Pada usia ini wanita memiliki kesempatan 95\% untuk hamil. Pada usia 30-an persentasenya menurun hingga $90 \%$. Sedangkan memasuki usia 40, kesempatan hamil berkurang hingga menjadi $40 \%$. Setelah usia 40 wanita hanya punya maksimal $10 \%$ kesempatan untuk hamil. Masalah kesuburan alat reproduksi merupakan hal yang sangat penting untuk diketahui. Dimana dalam masa wanita subur ini harus menjaga dan merawat kesehatan dan personal hygiene lat reproduksinya, salah satunya dengan melakukan deteksi dini kanker serviks pada wanita (Pallalo at.all. 2015). Berdasarkan penelitian yang dilakukan oleh Dokter Spesialis Obgyn ini, cikal bakal dari PCOS ada pada kondisi usus penderita. Ditemukan dalam usus wanita dengan PCOS terdapat gangguan resistensi insulin atau kepekaan terhadap hormon insulin. Resistensi insulin inilah yang mempengaruhi keseimbangan hormon reproduksi. Angka ini tentu saja meningkat setiap tahun. menimbang pola diet masyarakat saat ini yang semakin tidak seimbang dan cenderung menjalankan sendentary lifestyle di mana melakukan aktifitas fisik intensitas yang rendah dan malas bergerak dan berolahraga (Duta. 2021).

Perkembangan olahraga senam dewasa ini sudah sedemikian maju, khususnya senam aerobik yang sangat diminati ibu-ibu dan remaja putri baik di kota besar maupun di kota- kota kecil. Senam merupakan salah satu jenis latihan fisik yang digunakan sebagai sarana mencegah dan menurunkan berat badan serta sebagai sarana rehabilitasi atau terapi yang efektif. Memang banyak manfaat yang dapat diperoleh dari aktivitas ini, mulai dari meningkatkan kerja jantung, meningkatkan kekuatan otot, membakar lemak, serta manfaat-manfaat lainnya bagi tubuh (Lyne Brick, 2001). Berat badan adalah ukuran tubuh dalam sisi beratnya yang ditimbang dalam keadaan berpakaian minimal tanpa perlengkapan apapun. Berat badan diukur dengan alat ukur berat badan dengan satuan kilogram. Dengan mengetahui berat badan seseorang maka kita akan dapat memperkirakan tingkat kesehatan atau gizi seseorang (Surono 2000 dalam Mabella, 2010). Beberapa cara untuk mengatasi obesitas antara lain dengan berolahraga, diet dan menjaga pola makan. Latihan fisik jauh lebih baik menurunkan berat badan dibandingkan dengan dua intervensi lain. Keuntungan lain dari latihan fisik terlihat pada senam aerobik selama 10-15 menit 3 kali seminggu yang dapat mengendalikan tekanan darah dan lemak darah. Kegiatan pengabdian ini bertujuan untuk mengajak serta memberikan kesadaran kepada masyarakat untuk selalu menjaga kesehatan fisik melalui olaharga.

\section{Metode}

Metode yang digunakan yakni action research dengan tahapan Pelaksanaan kegiatan pengabdian ini dilaksanakan di desa cikoneng kecamatan sukahaji kabupaten majalenga melalui 
beberapa tahapan kegiatan dimulai dengan melakukan observasi pada tahap awal personalia penelitian mencari informasi tempat dan lokasi pada wilayah sasaran. Selanjutnya Persiapan sarana dan prsarana pada tahap persiapan sarana dan prasarana yang mendukung semua kegiatan seperti persiapan tempat dan lokasi kegatan senam aerobik dan penyuluhan kesehatan. Pada tahap pelaksanaan Kegiatan Pelaksanaan senam sehat diadakan dengan bertempat di lapangan terbuka depan Bale Desa Cikonen, sedangkan untuk penyuluhan menggunakan ruang rapat Desa Cikoneng.. A dapun Program Kegiatan Pelaksanaan Pengabdian Kepada Masyarakat (PKM) dilakukan selama 1 bulan pada jumat tgl 27 januari 2020 sampai 27 februari (selama 4-5 pertemuan 1 minggu sekali) dengan durasi waktu senam aerobic 45 menit dan penyuluhan 100 menit diawal pertemuan dan diakhir pertemuan. mengingat penyebaran virus dimasa pandemic covid 19 jadi waktu lebih singkat. Selanjutnya tabulasi data dan evaluasi hasil akhir.

\section{Hasil dan Pembahasan}

Persiapan awal kegiatan yang dilakukan dalam pengabdian ini dengan melaksanakan tiga kegiatan diantarnya yaitu: Kegiatan awal menjalankan protokol kesehatan sebagai pencegahan karena dilakukan dalam masa pandemik.

Selanjutnya kegiatan inti Penyuluhan/Pendidikan Kesehatan serta asupan gizi yang baik untuk mempertahankan berart badan ideal, olahraga yang mudah dan murah dilakukan oleh wanita usia subur yakni dengan melakukan senam aerobic yang dapat menurukan masa lemak dalam tubuh serta meningkatkan kebugaran agar tidak mudah sakit.

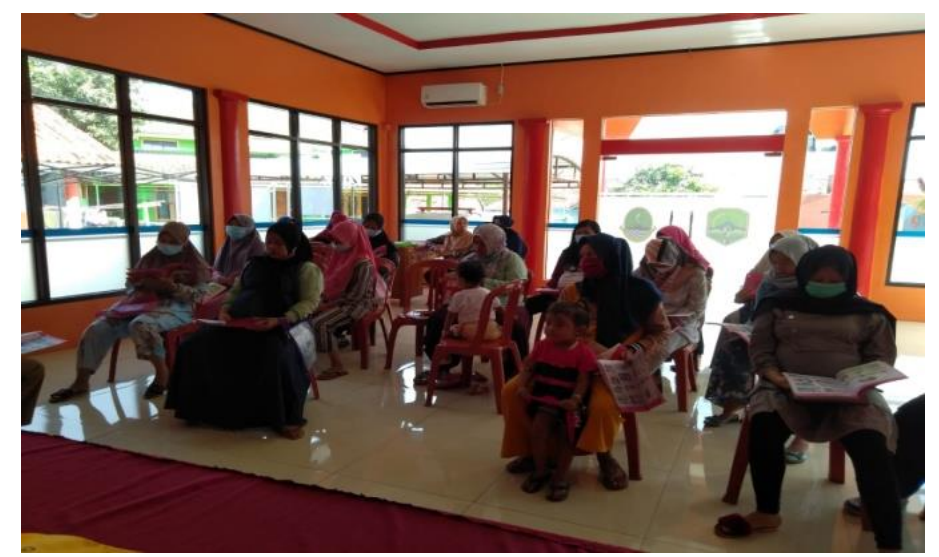

Gambar 1. Penyuluhan tentang pola hidup sehat

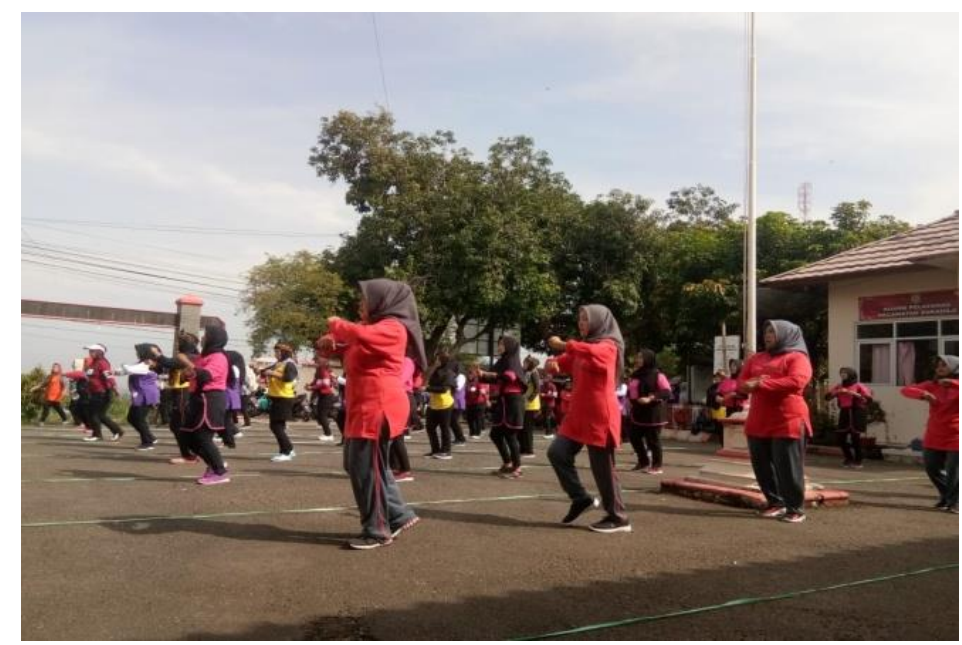

Gambar 2. Senam Aerobik 
Kegiatan penutup Setelah melaksanakan kegiatan senam aerobik dan penyuluhan, kemudian diberikan pengarahan serta pemahaman bahwa kegiatan yang dilakuakan sangat bermanfaat bagi tubuh kita dalam menjaga kesehatan guna meningkatkan kebugaran dan menjaga berat badan ideal supaya tidak mudah terserang berbagai penyakit.

Dari hasil analisa data, ditemukan beberapa masalah kesehatan dimasa pandemik dengan tidak memperhatikan bahwa olahraga dapat meningkatkan imunitas tubuh di masyarakat Blok 1 Desa cikoneng Kecmatan Sukahaji sebagai berikut:

a. Kurangnya pemahaman masyarakat terhadap pentingnya perilaku hidup sehat,.serta jarang melakukan olahraga untuk meningkatkan kebuaran, kerap kali asupan kalori yang masuk tidak seimbang dengan pengeluaran

b. Tidak adanya kegiatan olahraga secara terstruktur yang dilakukan secara rutin dan berkesinambungan, sehingga hormonal yang ada ditubuh wanita usia subur mengalamimkegemukan apalagi mereka yang memasang alat kontrasepsi misalnya KB Suntik.

\section{Kesimpulan}

Hasil Kegiatan senam aerobik dan penyuluhan kesehatan berupa perilaku hidup sehat, manfaat melakukan olahraga secara berkesinambungan dapat meningkatkan imunitas tubuh. Olahraga dengan senam aerobik tergolong olahraga yang mudah dilakukan, penanganan dan, serta asupan gizi yang baik untuk kesehatan tubuh. Pelaksanaan kegiatan ini mendapat respon yang baik dari tokoh agama, tokoh masyarakat, remaja dan masyarakat sendiri serta pemerintahan setempat. Antusias masyarakat terbukti dengan kehadiran masyarakat mengikuti kegiatan pengabdian masyarakat, dari $100 \%$ undangan yang disebar luaskan ada 60 sampai dengan $70 \%$ masyarakat yang menghadiri kegiatan tersebut.

\section{Daftar Pustaka}

Alex, M. S., \& Subiyono, H. S. (2012). Pengaruh Latihan Senam Aerobik Low Impact dan High Impact Terhadap Kesegaran Jasmani. Journal of Sport Science and Fitness, 1(1).

Amalia, L., \& Hiola, F. (2020). Analisis Gejala Klinis Dan Peningkatan Kekebalan Tubuh Untuk Mencegah Penyakit Covid-19. Jambura Journal of Health Sciences and Research, 2(2), 71-76.

Aung, M. N., Yuasa, M., Koyanagi, Y., Aung, T. N. N., Moolphate, S., Matsumoto, H., et al. (2020). Sustainable health promotion for the seniors during COVID-19 outbreak: A lesson from Tokyo. [Article]. Journal of Infection in Developing Countries, 14(4), 328-331. Candra, A. T.,

Candrawati, S., Sulistyoningrum, E., agung Prakoso, D. B., \& Pranasari, N. (2016). Senam Aerobik Meningkatkan Daya Tahan Jantung Paru dan Fleksibilitas. Jurnal Kedokteran Brawijaya, 29(1), 6973.

Fujimori, S., Maruo, S. J., Watanabe, T., Taki, N., Sasamori, F., Kobayashi, K., et al. (2020). Effectiveness of a Japanese-style health program in Minowa Town, Matsumoto city and Nagano city, Japan. [Article]. International Journal of Human Rights in Healthcare, 13(4), 347363.

Listyarini, A. E. (2012). Latihan Senam Aerobik untuk Meningkatkan Kebugaran Jasmani. Medikora, $1(2)$.

Mohamed, A., \& Alawna, M. (2020). Role of increasing the aerobic capacity on improving the function of immune and respiratory systems in patients with coronavirus (COVID-19): $A$ review. Diabetes \& Metabolic Syndrome: Clinical Research \& Reviews.

Nugraha, A. R., \& Berawi, K. N. (2017). Pengaruh high intensity interval training (HIIT) terhadap kebugaran kardiorespirasi. Jurnal Majority, 6(1), 1-5. 